\title{
PRACTICAL APPLICATION OF FORMS AND TOOLS OF MARKETING COMMUNICATION IN THE SME SECTOR
}

\author{
Małgorzata Adamska'
}

\footnotetext{
1 Opole University of Technology, Faculty of Economics \& Management, Department of Organization and Enterprise Management, Poland, ORCID: 0000-0001-5227-3519, m.adamska@po.edu.pl.
}

\begin{abstract}
This paper aims to investigate the application of different types of communication forms and tools (personal, audio/video, online, offline) in the context of client capital management and development of the client lifetime value in the sector of small and medium enterprises.

Research survey made using computer-assisted telephone interviewing, over 383 small and medium enterprises from the Opole Voivodeship region, with correlation coefficients for the selected variables (company size, market segment, markets serviced). The research contributes to enrichment of literature by documenting activity of small and medium enterprises in the area of marketing communication. This research illustrates the use of diverse forms and tools by diverse members of the SME sector. More importantly, this research prepares conclusions for future development of communication as a main stimulator of increasing client lifetime value.

The findings show that the small and medium enterprises are aware of the need to use a variety of tools to communicate with clients. The tools are diverse and have a different degree of contact intensity, which effectively contributes to the involvement of clients in the relationship with the company's offer. These contribute to the perceived value of client capital in the future. The findings suggest that in the future SME sector will develop and diversify channels of communication with clients capital, regardless of whether it concerns B2B or B2C clients. For the enterprise, the most important thing will be constant development of the client's lifetime value.

The popularization of knowledge about currently used communication forms and tools will contribute to the implementation of benchmark-based solutions by other market participants. In the future, it may have a beneficial effect on the client capital management process.
\end{abstract}

Keywords: Marketing communication, consumer behavior, client capital management, client value, SME.

JEL Classification: M31.

APA Style Citation: Adamska, M. (2020). Practical Application of Forms and Tools of Marketing Communication in the SME Sector. E\&M Economics and Management, 23(2), 193-209. https://doi.org/10.15240/tul/001/2020-2-013

\section{Introduction}

How can you imagine the future of marketing communication? The last several decades have brought the unexpected development of marketing concepts and tools (Keller, 2009), conditioned by changes in the economic environment: globalization processes, internationalization of enterprises, increase in competitiveness, social change, development of information technology, popularization of pro- innovation culture and, finally, "acceleration" of processes.

Against the background of these market conditions, presentation and analysis of currently used communication forms and tools in the sector of small and medium enterprises, in terms of types and forms of messages, seems to be a very interesting topic and will enable diagnosing existing status and drawing conclusions about future organizational 
behaviour in this area. The need for conducting this kind of research results from constant changes in the architecture of marketing communication.

The aim of the study was to learn the approach of small and medium entrepreneurs to customer value management processes through the prism of: quantity, intensity, quality of communication forms and tools. The research problem is the answer to the question: what forms and tools of marketing communication find practical application in the SME sector?

\section{Marketing Communication in Building Brand Loyalty}

Marketing communication is a process of information exchange creating relations and network of connections between an enterprise and market environment entities and its other market stakeholders. Communication is the process of conveying thoughts and sharing the meanings among individuals or organizations (Saeed, Naeem, Bilal, \& Naz, 2013). The introduction of the concept of integrated marketing communication was aimed to emphasis the creation of unified and seamless experience for consumers to interact with the brand. Many companies has recognize the need to integrate various marketing communications efforts, such as advertising, sales promotion, persolan selling direct marketing and of course public relations, which are the basic elements of marketing communications (Kotler \& Armstrong, 2011), to achieve more effective marketing communications (Belch \& Belch, 2004).

Marketing communication in the last dozen of years evolves faster and more intensively, in a significantly noticeable way both by customers and enterprises than it was decades before. Tremendous changes that are observed in the area of mobile technology development, i.e. new communication channels and tools as well as the content and methods of their delivery to the market (Kotler \& Armstrong, 2011), have resulted in enormous dynamics and diversity of applied marketing strategies (Varadarajan, 2010). The marketer continously needs to develop communication plans with the consumer as the starting point to design effective communication strategies (Kitchen \& Burgmann, 2010). What seems to be unchanged is only the main goal of marketing communication, that is, information and interest, building experience with the presented offer (product, service, brand) and finally, encouraging to make a satisfactory purchase.

Kotler and Armstrong (2011) proposed the analysis of clients from the perspective of six stages, through which he passes under the influence of marketing messages. These are: brand awareness, knowledge about the offer, affection for a brand, own preferences, conviction to make a purchase decision and ultimately a purchase. It would be worth to expand this analysis to the stage of achieving satisfaction with use. Thus, the indirect goal of marketing communication is achieved, which is creating customer engagement, which translates to its loyalty to the brand. "Commitment is a primary indicator of (subsequent) relationship behaviors and that it is born of a complex set of determinants including trust" (Sargeant, 2004). Venetis and Ghauri define relationship commitment as a partner's intentional continuation of a business relationship (Venetis \& Ghauri, 2004).

The literature on the subject indicates that loyalty may be: brand attachment, satisfaction with possession, repeatability of purchases, brand engagement, affection for a brand, commanded emotions, trust in the brand, satisfaction with quality (Thomson, Mcinnis, \& Park, 2005; Malär, Krohmer, Hoyer, \& Nyffenegger, 2011; Smaoui \& Temessek Behi, 2011; Mohammad \& Alhamadani, 2011; Mittal \& Kamakura, 2001; Venetis \& Ghauri, 2004). Customer loyalty represents behavioral intentions rather than effective behaviour (Coehlo \& Henseler, 2012).

All elements that make up the loyalty to the brand are created, among others, through integrated marketing communication and determine the strength of a client's relationship with the brand (Berezan, Krishen, Tanford, \& Raab, 2017). In SME's "communication plays an important and strategic role because it affects trust, the company knowledge, the reputation of the company, the image of the brand and of the product, the consolidation of company culture and the ability of the company to develop relations both with customers and suppliers" (Cioppi \& Buratti, 2009, p. 3). But accordin to Ramasobana "SMEs do not have high degrees of marketing abilities necessary to create value for their stakeholders" (2017, p. 113). The analysis of the results of the study will allow to learn best practices that support their abilities in the area of marketing communication. 


\section{Marketing Communication Then and Now}

Traditional marketing communication had the dimension of mass information transmitted to the market. These activities were conditioned by possible communication channels (offline media). In most cases, this was one-way communication. The client gained knowledge only from the company - therefore it was a monopoly of knowledge about the offer. The only form of communication with other market participants was word-of-mouth marketing, but also in a limited form - direct contacts. The customer of today makes informed decisions and will make demands and influence advertisements or any other information received through marketing communication (Kitchen \& Burgmann, 2010).

The development of information technologies (and hence mobile technologies) contributed to the development of modern, personalized forms of communication (online media) because it caused the need to redesign the existing architecture of marketing communication. It applies to both the B2C and B2B sector. Enterprises must properly take advantage of the opportunities to improve the flow of information, both within the organization and to improve marketing communication processes with other participants of the business environment. Modern technologies enable and even enforce structural changes in the organization and functioning of individual departments of the enterprise, primarily in the area of broadly understood marketing activities. In the long run, they have a positive impact on the increase of efficiency, the potential of competitiveness and the increase in innovation of the solutions used and the proposed products or services (Adamska, 2012).

The genesis of these processes were changes in macroenvironmental factors (technological, economic, social and cultural). A global marketplace which becomes more transitory through the Internet leads to a customer-driven and focused marketing environment (Kitchen \& Burgmann, 2010).

Modern information society fully, though perhaps not consciously, accepted the progressing computerization of subsequent spheres of life. Its expansion, initially in the spheres of professional life, quickly moved to the spheres of private life, contributing to the systematic virtualization of the living space.
Gradually, also leading to significant changes in current social behaviour. It applies to relations such as: interpersonal communication, social bonds, support, recognition and a sense of belonging to a group. Mobile information technologies have contributed to the development and strengthening of ties created within virtual communities. It was also reflected in the change in consumer behaviour, which adapted to the conditions of e-business development, understood in general as the implementation of processes of: production, distribution, marketing and sales as well as distribution of goods using ICT networks. The mobile marketing model existed in a hypermedia environment assuming communication, in which political, economic and social barriers lost importance - globalization processes in the marketing dimension have crossed the boundaries between the company and its market. Communication on a global scale became a fact, being on the one hand the cause and on the other hand the effect of globalization processes taking place in the modern knowledge-based economy (Wiktor, 2002).

Marketing communication, carried out with the use of a mobile channel, gives greater opportunities to reach the recipient, at a specific moment, with a message tailored to his or her needs and adequate to the situation or place where he or she is in. This applies to both retail and business customers.

Mobile marketing has become a key element of the entire marketing communication system currently used by enterprises, integrating offline traditional marketing activities (personal contacts, telephone calls, written and printed words: catalogues, offers, cards, etc.) as well as online and mobile virtual marketing (audio/video contacts: sms, chat, forum, word written and published online, social media, etc.) (Sznajder, 2014). The tendency to combine different marketing concepts is the right course of action, significantly increasing the reach and degree of impact of marketing activities on the market. There is a significant difference in the performance of SME's on the basis of adopted marketing communication strategy (Ramasobana, 2017).

Integrated Marketing Communications (IMC) is a concept of marketing communication planning that combine and evaluate strategic role of different communication forms and tools 
to get the clarity, consistency and greater impast (Saeed et al., 2013). IMC helps in creating coordinated and consistent messages across various channels of communications (Kitchen \& Burgmann, 2010), to achieve superior communication effectiveness (Luxton, Reid, \& Mavondo, 2015).

\section{Marketing Communication as a Factor Increasing the Customer Lifetime Value}

Customer capital consists of current and past customers who interacted with a company and its products as well as future customers who may be interested in its offer later on. In this context, the ability to communicate and influence consumers is crucial for the processes of building company value and competitive position, and for guaranteeing its proper, sustainable functioning in the future (Adamska \& Minarova, 2014).

Behaviour of the consumer can be identified as the process of making decisions affecting the individuals and groups during the assessment, acquisition, use and further disposal of goods and services. Through adjusting their behavior for different groups of customers, entrepreneurs can better meet individual consumer's expectations and thereby create customer satisfaction and engagement (Coelho \& Henseler, 2012).

Client capital from the perspective of a client portfolio owned by a company and the possibility of acquiring new clients constitutes the basis for the assessment of market value. It gives the opportunity to evaluate current profits and develop forecasts for the future. The value of an enterprise can be measured by the value of past and future relationships (Villanueva \& Hanssens, 2007). The Kumar and Venkatesan team (2004) promoted the concept of CLV Customer Lifetime Value and CLV indicator, which in its design includes all factors relevant to the actual profitability of the client, current and future: revenues and expenses, as well as the whole customer behaviour having significance for mutual relations, shaped primarily through the service. Customer lifetime value should is defined as the sum of the discounted cash flows that a customer generates during the whole relationship with the enterprise (Tirenni, Labbi, Berrospi, Elisseeff, Bhose, Pauro, \& Pöyhönen, 2007). CLV is typically assessed using customer behavior data from the enterprise's database to predict customer behavior and profitability (Donkers, Verhoef, \& Jong, 2007).

Regardless of the methods of measuring the CLV index, it is important to implement actions in the areas of customer relationship management aimed at its systematic growth (Maycotte, 2015). "CLV is a disaggregate metric that can be used to identify profitable customers and allocate resources accordingly" (Gupta, Hanssens, Hardie, Kahn, Kumar, Lin, \& Sriram 2006, p. 140). Determining customer value can help managers in making decisions, for example, be used to decide how much to spend on promotional campaigns or to check the difference in profitability among various market segments (Berger \& Nasr, 1998).

Developed relationships with clients have the most important significance for the company's value in terms of achieving basic goals, such as increasing productivity, market shares and the reach of impact. In the context of market exchange and participants of exchange transactions, there is the concept of consumer management, which should be seen as a positive approach of consumers to the organization, by accepting values and activities implemented by them (Neumann, 2007). Marketing communication is responsible for transferring this knowledge to clients and small and medium enterprises are more responsive to the market expectations ( $\mathrm{Lu}$, 2014). It represents "the 'voice' of the company and its brands and are a means by which it can establish a dialogue and build relationships with and among consumer" (Keller, 2009, p. 141).

\section{Methods}

The presented issues have been selected from a wide range of the research "Managing relations with client capital in the sector of small and medium enterprises of Opole Voivodeship. Identification of customer value growth stimulators", financed by the National Science Center as part of a scientific grant in the Miniatura1 competition (Narodowe Centrum Nauki [NCN], 2017).

The aim of the research was to get to know entrepreneurs' approach to client value management processes, by identifying:

- the role and importance of a client in the development of an organization;

- the number, intensity, quality and complementarity of tools for cooperation with client capital. The required research 
sample was achieved and amounted 383 SMEs.

- data collection and processing methods and the ability to convert knowledge into innovation.

The questionnaire was designed for both SMEs operating in the B2B and B2C sectors. The study showed that the significant characteristics of the unit affecting the obtained results were: size of the enterprise, market type (B2B/B2C), customer segment.

The study was carried out using the CATI method whose strong side is certainly the implementation of the study through constant monitoring of the survey and respondents' reactions - personalization of contacts, verification of obtained data on an ongoing basis, preparation of data for analysis through the use of an electronic questionnaire.

The surveyed population totalled 100,295 , the required number of respondents was 383 , broken down by self employment, micro, small and medium enterprises. Confidence level in the study: $95 \%$. Maximum error: $5 \%$. The required research sample was achieved and amounted 383 SMEs (49.8\% micro enterprises, $57.4 \%$ small enterprises and $37.4 \%$ medium enterprises).

The creation of hypotheses took place by making hypothetical conclusions from the already existing theory, discovering the hypothesis by generalizing the collected data, and "getting into" social situations, or hypothesizing based on life experience and own conjectures. Detailed research hypotheses were formulated based on professional, life experience and inspiration resulting from everyday business practice. Due to conventional approach to content analysis research findings are addressed in the discussion section of the study. "The advantage of the conventional approach to content analysis is gaining direct information from study participants without imposing preconceived categories or theoretical perspectives. Also, knowledge generated from content analysis is based on respondents very unique perspectives and grounded in the actual data form the economic environment" (Hsieh \& Shannon, 2005, pp. 1280-1281).

For testing hypotheses the Chi-squared test of independence was implemented. The Chi-squared test of independence is one of the most basic and common hypothesis tests in the statistical analysis. It is a highly utilitarian nonparametric statistic facilitating the analysis of nominal data, typically in the form of frequencies. Traditionally, this inferential statistic compares observed frequencies with expected, with the latter generated by the null hypothesis or by theory (Bucalew \& Pearson, 1982). The data used in these tests are enumerative and the data are counts or frequencies. "The statistic is equal to the squared difference between the observed count and the expected count in each cell, divided by the expected count, summed over all cells" (Aczel \& Sounderpandian, 2008, pp. 661-662).

The Cramér's $V$ is the most common strength test used to test the data when a significant Chisquared result has been obtained (McHugh, 2013). Cramér's V statistic ranges from 0 to 1 , with higher values indicating larger strengths of associations (Kearney, 2017).

A proportional distribution to the number of entities in each poviat of the Opole Voivodeship was proposed, while at the level of the voivodship, targeted selection was introduced, with a proportional division of $1 / 3$ of the number of entities from each of the three distinguished groups. This made it possible to set minimum thresholds, guaranteeing obtaining data in representative groups, while providing some flexibility in the selection of the sample.

Despite the systematic approach to the presented research process, study limitations always appear and the study does not provide a complete, detailed picture of assessment. For example, the industry in which the surveyed enterprises operate was not taken into consideration in this analysis, which caused that the level of presented results is general. Another research limitation is the subjective approach in the assessment made by the researcher. However, it gives an overview of the current attitude of entrepreneurs to marketing communication.

\section{Presentation of Research Results Concerning Marketing Communication in the SME Sector}

The research involved enterprises operating on all markets in terms of geographical distribution (Tab. 1), and thus implementing marketing communication processes with a domestic and international customer, both on the B2B $(24.3 \%)$, B2C $(8.8 \%)$ and mixed markets $(66.8 \%)$.

The study was attended by entrepreneurs who, by operating on the market for many years, carry out marketing communication activities 


\section{Tab. 1: Decompositions of respondents due to size of the entity a type of market served}

\begin{tabular}{l|c|c|c}
$\begin{array}{c}\text { Type of market } \\
\text { served }\end{array}$ & $\begin{array}{c}\text { Micro-enterprise (average annual } \\
\text { employment up to 9 employees) }\end{array}$ & $\begin{array}{c}\text { Small enterprise } \\
\text { (10-49 employees) }\end{array}$ & $\begin{array}{c}\text { Medium enterprise } \\
\text { (50-249 employees) }\end{array}$ \\
\hline Local & $12.2 \%$ & $7.6 \%$ & $3.1 \%$ \\
\hline Regional & $7.1 \%$ & $7.8 \%$ & $3.1 \%$ \\
\hline National & $8.6 \%$ & $11.0 \%$ & $4.7 \%$ \\
\hline European Union & $3.4 \%$ & $7.8 \%$ & $7.0 \%$ \\
\hline Global & $3.2 \%$ & $5.5 \%$ & $7.8 \%$ \\
\hline
\end{tabular}

Source: own

\section{Fig. 1: Organization of customer service divided into the size of the enterprise}

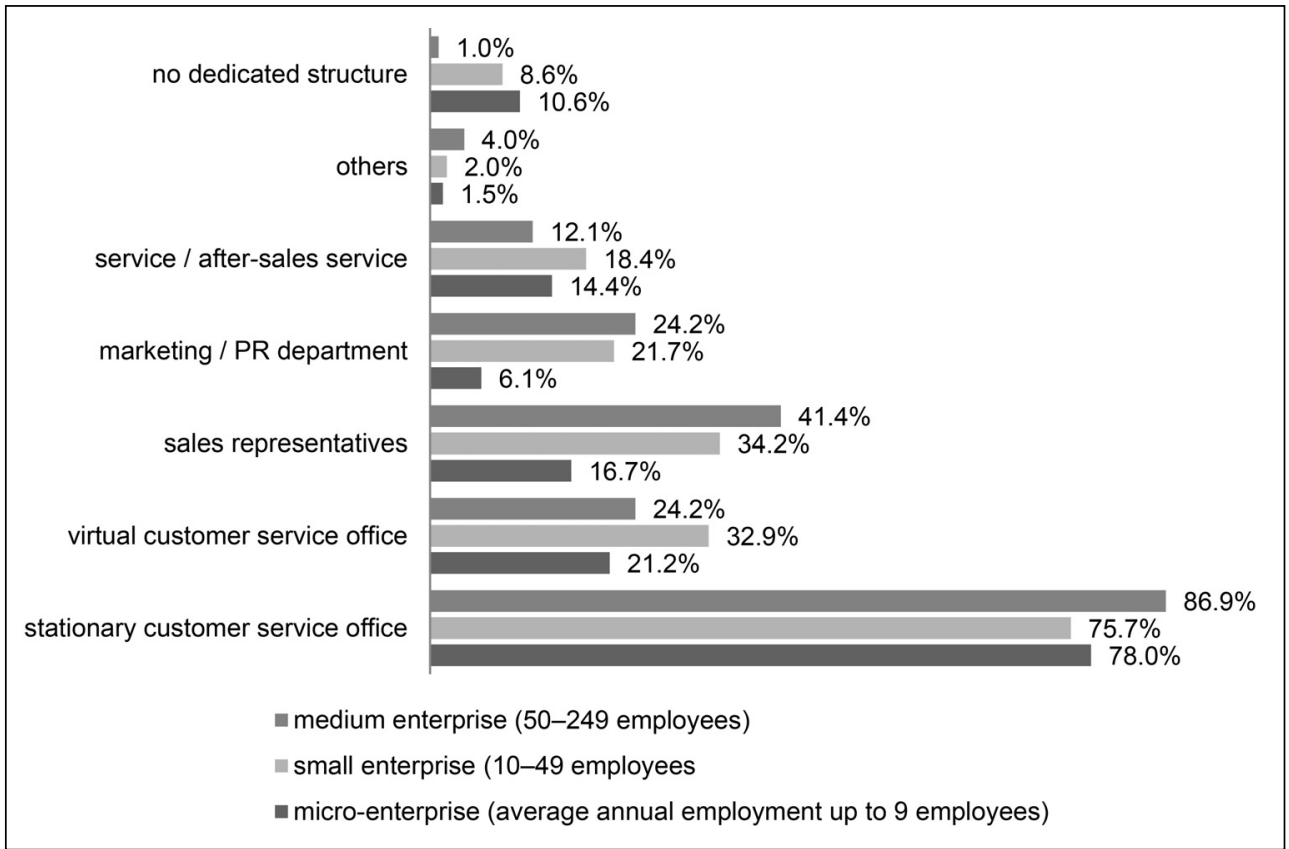

Source: own

and have knowledge about their development and the need for continuous, flexible adaptation to the requirements of business environment. Nearly $90 \%$ of respondents indicated having an established position on the market resulting from experience in running a business: $67.4 \%$ over 15 years; $11.2 \%-11-15$ years and $11.5 \%$ above 6 years.

Among many research questions regarding client capital, one of them was a question organizing the knowledge about respondents, about client groups divided into the frequency of making contacts with the company:

- $93.5 \%$ declared that they have regular customers who use the offer systematically;

- in the group of enterprises declaring having occasional customers using the offer from time to time, there were $62.4 \%$;

- $1.3 \%$ of respondents were not able to determine the characteristics of their clients. 
The study also checked how the structure of the company was organized and prepared for service and contacts with clients. The results, broken down by enterprise size, are presented in Fig. 1.

Stationary and virtual customer service offices are among the most popular forms for all types of enterprises. In medium-sized enterprises, the organizational structure for conducting marketing communication has been fully prepared, they have both stationary and virtual service offices, sales representatives and separate marketing and PR departments. This is due to the size, number of employees and greater opportunities in the scope of customer service organization.

The hypothesis for the Chi-squared test of independence for organization of customer service and the size of the enterprise:

$\mathrm{H}_{0}$ : Organization of customer service in an enterprise does not depend on the size of the enterprise - variables are independent.

$\mathrm{H}_{1}$ : Organization of customer service in an enterprise does depend on the size of the enterprise - variables aren't independent.

The significance level for a choosen hypothesis test is $\alpha=0.05$, and the $p$-value is $<0.01$. The empirical value of the Chisquared test statisticis is 33.58 and it exceeds the critical of 18.31 , so the hypothesis $H_{0}$ was rejected. Cramér's $V$ values of 0.316 indicate a strong relationship between variables. On the basis of the summary results, it can be concluded that the SME sector in its structures significantly distinguishes the departments responsible for activities in the area of marketing communication and the organization of customer service in an enterprise depends on the size of the enterprise.

In the course of the research, respondents indicated the most important, in their opinion, areas characterizing the approach to managing relations with client capital and activities undertaken in this respect in the enterprise (Fig. 2).

The hypothesis for the Chi-squared test of independence for characteristics of the customer approach in an enterprise and the size of the enterprise:

$H_{0}$ : Activities in the area of the customer approach in an enterprise does not depend on the size of the enterprise - variables are independent.

$H_{1}$ : Activities in the area of the customer approach in an enterprise does depend on the size of the enterprise - variables aren't independent.

The empirical value of the Chi-squared test statistic is less than the critical value of 21.03, so the hypothesis $H_{0}$ was accepted (Tab. 2). The significance level for a choosen hypothesis test is $\alpha=0.05$ and the $p$-value is greater, so

\section{Fig. 2: Characteristics of the customer approach in an enterprise - highest results}

adapted its activity to the needs and expectations of a client

uses proper tools to maintain relationship with a client

has an organizational structure geared to the customer

establishing strategic and operational plans emphasize the role of a client

gets the necessary information about a client's needs

anticipates future expectationsof customers introduces innovations into the sphere of cooperation with a client

tries to create the market which it operates on manages client value

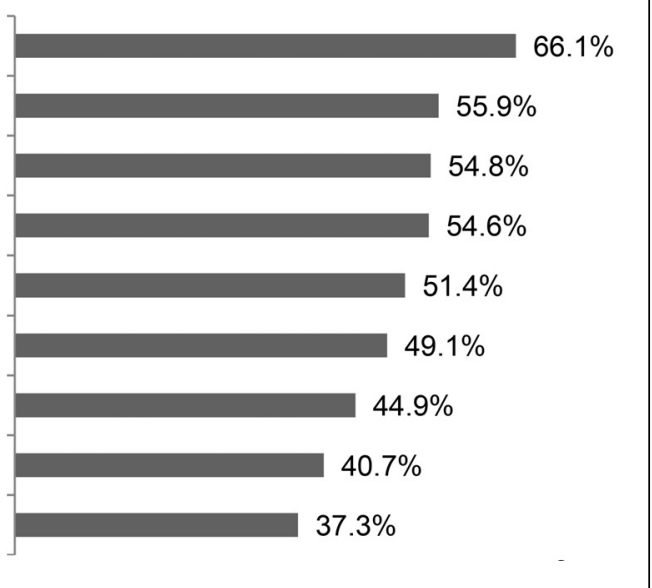

Source: own 


\begin{tabular}{|c|c|c|c|c|c|}
\hline & $\begin{array}{c}\text { Chi-squared } \\
\text { test }\end{array}$ & $\begin{array}{l}\text { Degrees } \\
\text { of freedom }\end{array}$ & P-value & $\begin{array}{l}\text { Critical } \\
\text { values of the } \\
\text { Chi-squared }\end{array}$ & $\begin{array}{c}\text { Cramér's } \\
\text { V }\end{array}$ \\
\hline $\begin{array}{l}\text { Adapted its activity to the needs } \\
\text { and expectations of a client. }\end{array}$ & 12.38 & \multirow{9}{*}{12} & 0.416 & \multirow{9}{*}{21.03} & 0.36 \\
\hline $\begin{array}{l}\text { Has an organizational structure } \\
\text { geared to the customer. }\end{array}$ & 8.61 & & 0.736 & & 0.30 \\
\hline $\begin{array}{l}\text { Establishing strategic and } \\
\text { operational plans emphasize the } \\
\text { role of a client. }\end{array}$ & 10.37 & & 0.584 & & 0.33 \\
\hline $\begin{array}{l}\text { Uses proper tools to maintain } \\
\text { relationship with a client. }\end{array}$ & 5.34 & & 0.946 & & 0.24 \\
\hline Manages client value. & 6.06 & & 0.913 & & 0.25 \\
\hline $\begin{array}{l}\text { Anticipates future expectationsof } \\
\text { customers. }\end{array}$ & 5.50 & & 0.939 & & 0.24 \\
\hline $\begin{array}{l}\text { Tries to create the market which it } \\
\text { operates on. }\end{array}$ & 5.94 & & 0.919 & & 0.25 \\
\hline $\begin{array}{l}\text { Introduces innovations into } \\
\text { the sphere of cooperation with } \\
\text { a client. }\end{array}$ & 7.60 & & 0.816 & & 0.28 \\
\hline $\begin{array}{l}\text { Gets the necessary information } \\
\text { about a client's needs. }\end{array}$ & 10.10 & & 0.607 & & 0.32 \\
\hline
\end{tabular}

there is not enough evidence to reject the null hypothesis.

Also Cramér's $V$ values indicate a weak relationship between variables. Activities in the area of the customer approach in an enterprise does not depend on the size of the enterprise.

Entrepreneurs, according to their selfdescription, stated that they adapted their activities to the needs and expectations of a client, more than half of them use proper tools to maintain relations with a customer and have an organizational structure geared to the client. While establishing strategic and operational plans they emphasize the role of a client. The sector of small and medium-sized enterprises can therefore boast the implementation of a marketing concept focused on the needs and expectations of customers. The weakest result was obtained by managing the customer value (37.3\%). This result may also indicate a lack of awareness of what actions constitute the management of the client's value and the perception of this concept only through the accounting and financial aspect. An element worthy of support will be the promotion of client value management tools and the proposal of solutions in the area of assessment indicators selection.

In terms of the communication methods used in the organization for contact with a client, the respondents were offered a division into: personal (Fig. 3), audio/video (Fig. 4) and verbal/printed ones (Fig. 5). The respondents could evaluate the given variants of communication on a scale from 1 to 5 , where 1 meant the least-used, and 5 the most frequently-used form.

In the case of personal communication forms (Fig. 3), all variants were assessed as of little importance, with no clear differences due to the markets served.

Participation in fairs and organization of trade shows and workshops was recognized as the most important used form of this kind of communication. It is a popular form of marketing communication because it allows for a wide presentation of new products, deepening the market through an interesting offer for existing products or for developing contacts 


\section{Fig. 3: Forms and tools of communication - personal}

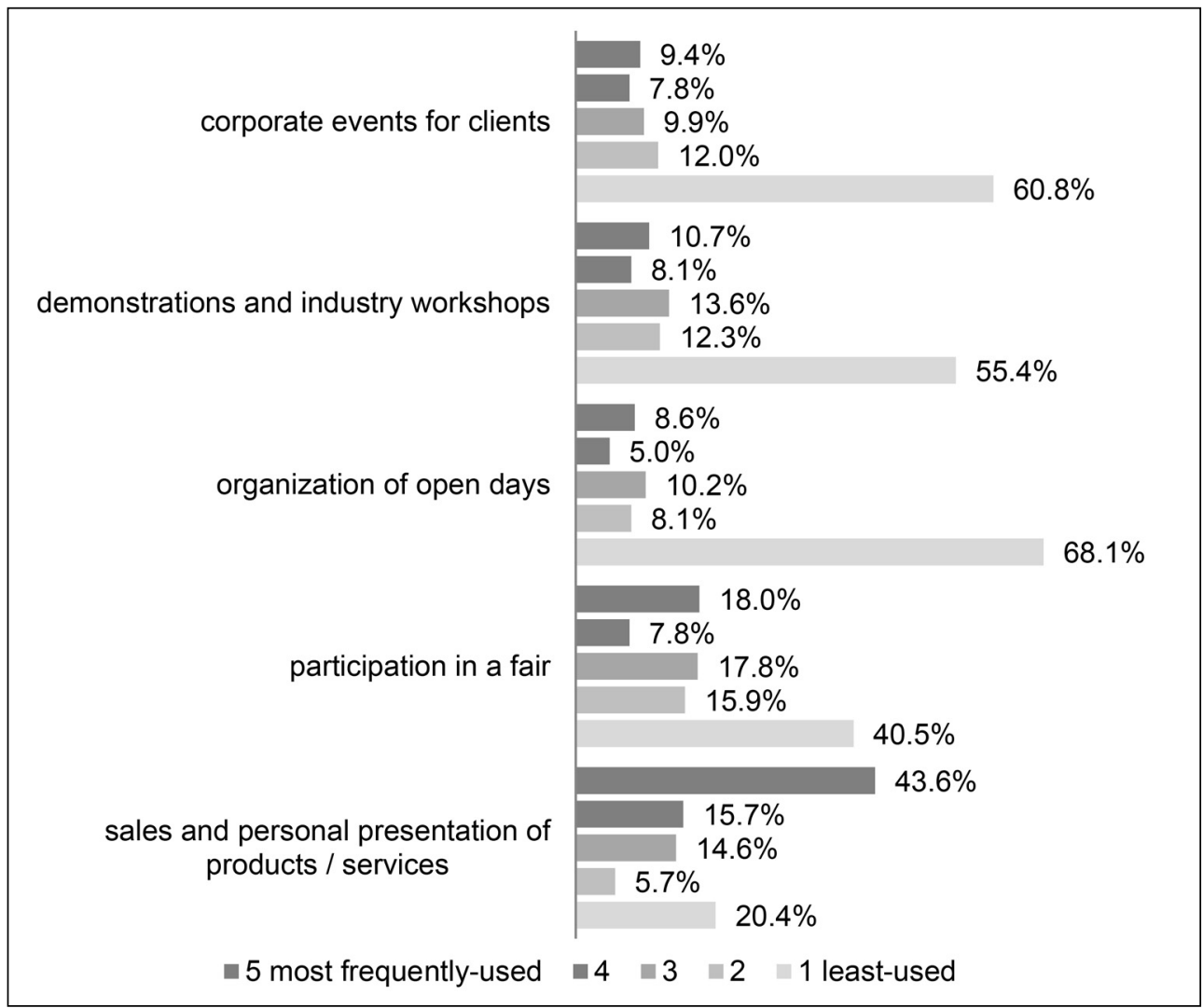

Source: own

between business partners. Respondents treat it as a secondary one, which can be a complementary form for more frequently used forms of communication. A crucial factor is also the limited access of customers to the fair offer, resulting from their frequency and location.

The hypothesis for the Chi-squared test of independence for used forms and tools of communication - personal and the segments of a market served:

$H_{0}$ : The use of personal forms and tools of communication in an enterprise does not depend on the segments of a market served variables are independent.

$H_{1}$ : The use of personal forms and tools of communication does depend on the segments of a market served - variables aren't independent.
The empirical value of the Chi-squared test statistic is less than the critical value of 15.5. The hypothesis $H_{0}$ was accepted (Tab. 3). The $p$-vaule is greater then the significance level for a choosen hypothesis test $\alpha=0.05$. Also Cramér's $V$ values indicate a weak relationship between variables. So, the use of personal forms and tools of communication in an enterprise does not depend on the segments of a market served.

In relation to forms of audio/video communication (Fig. 4), traditional telephone connections were considered the most frequently used in business practice. Nearly $70 \%$ of respondents use video phone calls/ video conferencing the least frequently. With regard to instant messengers, opinions are divided, $38.9 \%$ of respondents indicate this 


\begin{tabular}{|c|c|c|c|c|c|c|}
\hline \multirow[t]{2}{*}{ Tab. 3: } & \multicolumn{6}{|c|}{$\begin{array}{l}\text { Chi-squared test of independence for forms and tools of communication } \\
\text { - personal }\end{array}$} \\
\hline & & $\begin{array}{c}\text { Chi-squared } \\
\text { test }\end{array}$ & $\begin{array}{l}\text { Degrees } \\
\text { of freedom }\end{array}$ & P-value & $\begin{array}{l}\text { Critical } \\
\text { values of the } \\
\text { Chi-squared }\end{array}$ & $\underset{V}{\text { Cramér's }}$ \\
\hline \multicolumn{2}{|c|}{$\begin{array}{l}\text { Sales and personal presentation } \\
\text { of products/services }\end{array}$} & 8.24 & \multirow{5}{*}{8} & 0.411 & \multirow{5}{*}{15.5} & 0.21 \\
\hline \multicolumn{2}{|c|}{ Participation in a fair } & 12.79 & & 0.119 & & 0.26 \\
\hline \multicolumn{2}{|c|}{ Organization of open days } & 11.88 & & 0.156 & & 0.25 \\
\hline \multicolumn{2}{|c|}{$\begin{array}{l}\text { Demonstrations and industry } \\
\text { workshops }\end{array}$} & 13.19 & & 0.105 & & 0.26 \\
\hline \multicolumn{2}{|c|}{ Corporate events for clients } & 12.03 & & 0.15 & & 0.25 \\
\hline
\end{tabular}

\section{Fig. 4: Forms and tools of communication - audio/video}

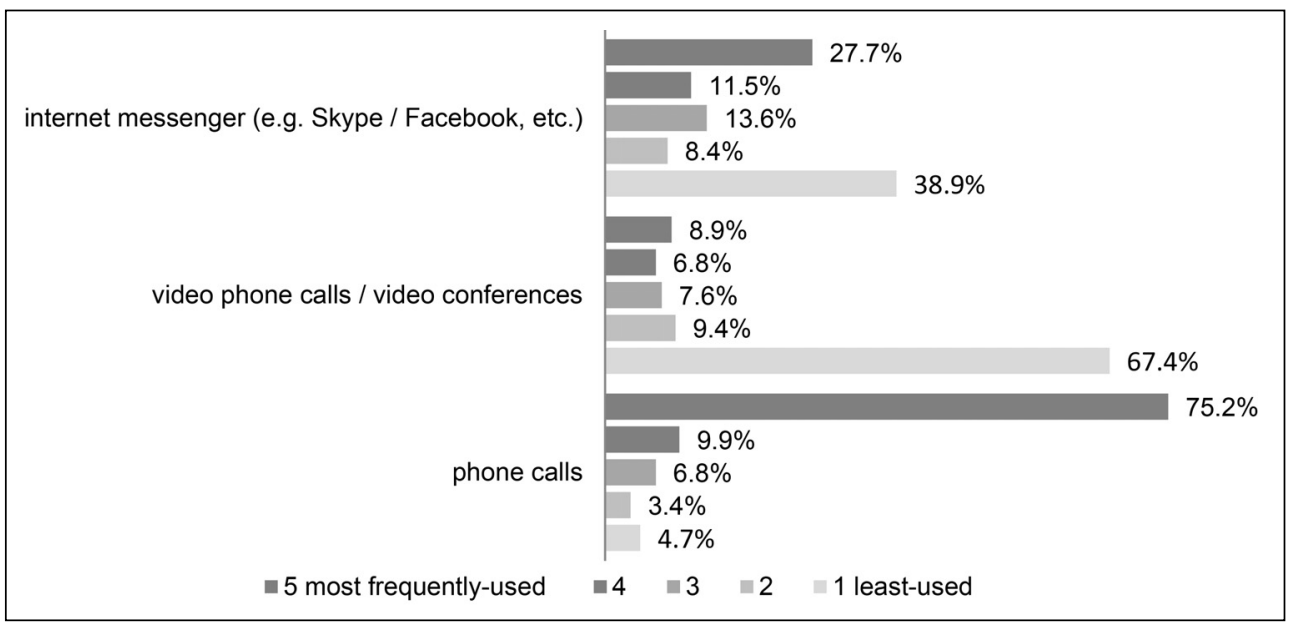

Source: own

form of communication as the least-used one, and $27.7 \%$ as the most frequently used one. This assessment of instant messengers was surprising due to the growing popularity of mobile communication.

However, it can be inferred that this is a reflection of a natural evolution of communication with a client. The use of Internet messengers seems to be a more popular form of contact because it is made mainly with the use of a computer, which makes it easier to share documents and work through a remote desktop. It is therefore a more convenient form of contact in the space of a stationary or virtual customer service office, rather than video telephone calls.

The hypothesis for the Chi-squared test of independence for used forms and tools of communication - audio/video and the segments of a market served:

$H_{0}$ : The use of audio/video forms and tools of communication in an enterprise does not depend on the segments of a market served variables are independent.

$H_{1}$ : The use of audio/video forms and tools of communication does depend on the 


\begin{tabular}{l} 
Tab. 4: Chi-squared test of independence for forms and tools of communication \\
- audio/video \\
\cline { 1 - 2 }
\end{tabular}

segments of a market served - variables aren't independent.

The empirical value of the Chi-squared test statistic is less than the critical value of 15.5 , so the hypothesis $H_{0}$ was accepted (Tab. 4). The significance level for a choosen hypothesis test is $\alpha=0.05$ and the $p$-value is greater, so there is not enough evidence to reject the null hypothesis. Also Cramér's V values indicate a weak relationship between variables. So, the use of audio/video forms and tools of communication in an enterprise does not depend on the segments of a market served.

The last analyzed form of communication was verbal/printed communication (Fig. 5), among which the offline and online communication tools were distinguished. Offline communication tools (such as a catalogue, greeting card or printed forms) are used by over a quarter of respondents, which again can be considered as the confirmation of the thesis that there is a systematic process of changes in the use of communication tools.

On the local markets, traditional communication tools with clients work better because they do not see the need for more advanced applications. Contact with the client is direct and personal in their case. However the extent of modern markets requires the use of online communication tools.

As the most frequently used form of verbal/ printed communication with the customer, the largest percentage of respondents indicated e-mailing, followed by a website in terms of frequency of indications. On the other hand, among the least frequently used forms of contact between organizations and clients the highest percentage of respondents indicated online chat, then discussion forums and a newsletter. They can be described as communication tools that work well for large enterprises in selected industries (e.g. banking, telecommunications). The indicated tools can be considered as "standard equipment" for modern websites, however entrepreneurs from the SME sector do not find practical use of them in their activities. Each of these tools also requires a lot of time for administrationediting. For entrepreneurs it may be the unnecessary expense of time, energy and finances, considering the anticipated economic effects.

The hypothesis for the Chi-squared test of independence for used forms and tools of communication - verbal/printed and the segments of a market served:

$H_{0}$ : The use of verbal/printed forms and tools of communication in an enterprise does not depend on the segments of a market served - variables are independent.

$H_{1}$ : The use of verbal/printed forms and tools of communication does depend on the segments of a market served - variables aren't independent.

The empirical value of the Chi-squared test statistic is less than the critical value of 15.5 , for nine out of twelve verbal/printed forms and tools of communication. The hypothesis $H_{0}$ was accepted (Tab. 5). Also Cramér's $V$ values indicate a weak relationship between variables. The coefficient reaches very low values for: catalogue/offer, newsletter, discussion forum. The significance level for a chosen hypothesis test is $\alpha=0.05$. The $p$-vaule is greater then $\alpha$, so there is not enough evidence to reject the null hypothesis for the indicated forms of communication. So, the use of presented in Tab. 6 verbal/printed forms and tools of communication in an enterprise does not depend on the segments of a market served.

The empirical value of the Chi-squared test statistic exceeds the critical of 15.5 , for 3 out 
Tab. 5:

Chi-squared test of independence for forms and tools of communication - verbal/printed - hypothesis $\mathrm{HO}$ was accepted

\begin{tabular}{|c|c|c|c|c|c|}
\hline & $\begin{array}{l}\text { Chi-squared } \\
\text { test }\end{array}$ & $\begin{array}{l}\text { Degrees of } \\
\text { freedom }\end{array}$ & P-value & $\begin{array}{l}\text { Critical } \\
\text { values of the } \\
\text { Chi-squared }\end{array}$ & $\underset{V}{\text { Cramér's }}$ \\
\hline Catalogue/offer & 3.11 & \multirow{9}{*}{8} & 0.927 & \multirow{9}{*}{15.5} & 0.127 \\
\hline Printed forms/online forms & 14.66 & & 0.066 & & 0.277 \\
\hline $\begin{array}{l}\text { Client profile available on } \\
\text { a website for clients }\end{array}$ & 8.89 & & 0.352 & & 0.215 \\
\hline Newsletter & 3.67 & & 0.886 & & 0.138 \\
\hline $\begin{array}{l}\text { Social networks } \\
\text { (Facebook, Twitter, Instagram, etc.) }\end{array}$ & 13.16 & & 0.091 & & 0.262 \\
\hline Online chat & 9.79 & & 0.280 & & 0.226 \\
\hline Sms & 9.86 & & 0.275 & & 0.227 \\
\hline Greeting cards & 13.75 & & 0.089 & & 0.268 \\
\hline Discussion forums & 4.78 & & 0.781 & & 0.158 \\
\hline
\end{tabular}

of 12 forms and tools of communication, so the hypothesis $H_{0}$ was rejected for: printed forms/ paper forms (traditional mail), website, emailing. Cramér's $V$ values indicate a strong relationship between variables and the $p$-value is lower then a. So, the use of presented in Tab. 6 verbal/ printed forms and tools of communication in an enterprise does depend on the segments of a market served.

High popularity of other online marketing communication tools stems from the fact that they give the possibility to create a marketing message in an interactive and more effective way, which is reflected in the achieved results. When it comes to the use of websites - the interaction between a brand and a customer proceeds in a more free manner, which increases the integration and involvement of customers by eliminating some of the barriers preventing proper familiarization with the content and aesthetics of the marketing message. The development of mobile information technologies and their application in marketing activities of enterprises eliminated the barriers of time, space and distance within marketing communication (Krum, 2012). The study also checked which factors determined the decision to choose such forms of communication with client capital (Fig. 6).

Most often the respondents indicated the universality of access, while enterprises operating on the B2C market indicated the importance of universal access at the level of $67.6 \%$. The next place was efficiency which was the most important for companies operating on the B2B market $-54.8 \%$. The ease of use factor was indicated by $44.4 \%$ of respondents, but there were no significant differences in the

Tab. 6:
- verbal/printed - hypothesis $\mathrm{HO}$ was rejected

\begin{tabular}{|c|c|c|c|c|c|}
\hline & $\begin{array}{c}\text { Chi-squared } \\
\text { test }\end{array}$ & $\begin{array}{l}\text { Degrees } \\
\text { of freedom }\end{array}$ & P-value & $\begin{array}{c}\text { Critical } \\
\text { values of the } \\
\text { Chi-squared }\end{array}$ & $\begin{array}{c}\text { Cramér's } \\
\text { V }\end{array}$ \\
\hline $\begin{array}{l}\text { Printed forms/paper forms } \\
\text { (traditional mail) }\end{array}$ & 25.73 & \multirow{3}{*}{8} & 0.001 & \multirow{3}{*}{15.5} & 0.366 \\
\hline Website & 26.42 & & 0.001 & & 0.371 \\
\hline Emailing & 25.43 & & 0.001 & & 0.364 \\
\hline
\end{tabular}




\section{Fig. 5: Forms and tools of communication - verbal/printed}

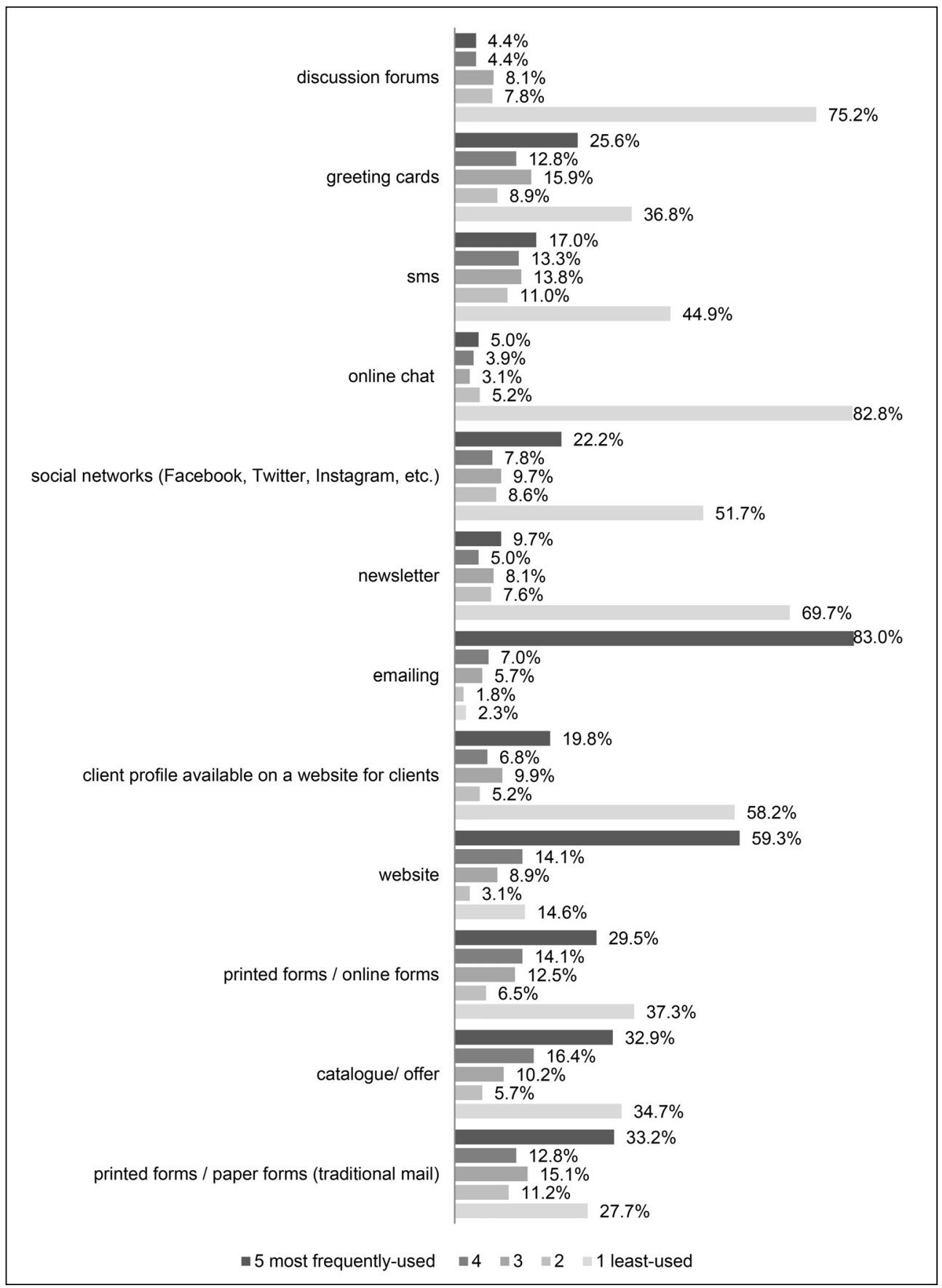




\section{Fig. 6: Determinants of choosing communication forms}

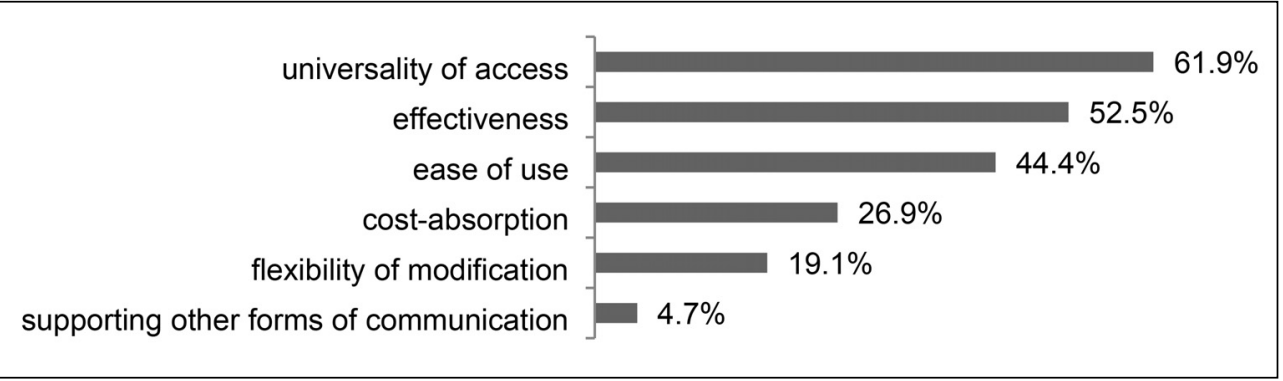

division into market segments. The economic factor - costs - was significant for just over $1 / 4$ of respondents and was indicated as the most important by self-employed (33.3\%).

The hypothesis for the Chi-squared test of independence for determinants of choosing communication forms and the size of the enterprise:

$H_{0}$ : Determinants of choosing communication forms in an enterprise does not depend on the size of the enterprise - variables are independent.

$H_{1}$ : Determinants of choosing communication forms in an enterprise does depend on the size of the enterprise - variables aren't independent.

The empirical value of the Chi-squared test statisticis is 7.59 and it exceeds the critical of 18.31, hypothesis $H_{0}$ was accepted. The significance level for a choosen hypothesis test is $\alpha=0.05$ and the $p$-vaule is greater, so there is not enough evidence to reject the null hypothesis. Cramér's V values of 0.137 indicate a weak relationship between variables.

Factors determining the choice of forms of communication in the sector of small and medium enterprises are in line with current market conditions. According to Internet World Stats (2017) the number of Internet users at the end of 2017 amounted to over 4.1 billion, of which $17 \%$ are in Europe. According to Eurostat (2018), also for 2017 , the vast majority (93\%) of enterprises in the EU-28 use a fixed broadband connection to access the Internet, and $77 \%$ have a website. Central Statistical Office (2017) determined that in Poland this percentage was nearly $95 \%$, of which $67 \%$ had their website.

\section{Reseach Results Summary}

Analyzing the results of research in the area of selected issues, which were undertaken in a wider study entitled Managing relations with client capital in the SME sector in Opole Voivodeship. Identification of customer value growth stimulators, it can be summarized that enterprises have both permanent and occasional clients. Regardless of the size, the enterprises adapted their structure for full and effective customer service (Fig. 1) using primarily stationary and virtual service offices, sales representatives and dedicated marketing departments. Thus, in economic practice function traditional economic forms of communication as well as modern ones connected with development of information technologies.

Entrepreneurs are aware that customer orientation is a key to achieving market success (Fig. 2) by adapting their business to their needs and expectations. The SME sector does not implement sufficiently the concept of client value management, however, it should be recognized that undertaking marketing activities support the creation of client value for the company. Solutions to support entrepreneurs in systematising their activities in this area should be proposed.

The most popular communication methods used in the organization for personal contact with a client are: participation in a fair and demonstrations and industry workshops, but their use is not widespread (Fig. 3). Among the used forms of marketing communication traditional telephone contacts and instant messengers outweigh personal contacts 
(Fig. 4), while the most commonly used forms of communication are e-mailing and websites (Fig. 5). The forms of communication selected by the respondents indicate their adaptation to the expectations of clients who, thanks to the information they receive via an e-mail or via a website, have the opportunity to familiarize themselves with its terms and analyze the benefits. Phone contact or instant messengers are only a tool for establishing and refreshing relations with customers. They are, therefore, typically complementary tools. They also fully meet the contemporary market conditions in the field of use of mobile information technologies.

The main factor in the selection of these forms of communication was primarily the universality of access and efficiency (Fig. 6) which confirms the orientation towards a client. The SME sector, in major part, carries a high risk of doing business mainly due to financial issues. Entrepreneurs look for such forms and tools of communication that will not require large financial expences and at the same time will be effective. These forms of communication are chosen which can guarantee the widest possible audience.

\section{Conclusion}

Changes in consumer behavior are a key factor conditioning such dynamic development of communication forms and tools, but of course also changes that improve technology were important certainly for creating modern marketing communication. The standard of modern times is the fact that customers use the Internet to satisfy a wide spectrum of their needs and the SME sector, regardless of their size, the market they operate on and the segments they target, must do everything to meet those expectations.

The results of the survey indicate that the SME's sector is already using wide range of forms and tools of marketing communication: personal (Fig. 3), audio/video (Fig. 4) and verbal/printed ones (Fig. 5). Certainly, the presented combination of different marketing communication strategies yields better results for SMEs in terms of performance as compared to when used individually, so therefore, integration should be one of the priorities in the future, because currently entrepreneurs do not pay much attention to it (Fig. 6).

Center of gravity in IMC shifted from personal communication to the level of indirect communication with the use of modern technologies, but still some of them, like sales and personal presentation of products/services are practiced, also catalogues and printed form of communication are popular, so entrepreneurs should not give up on them. In the future they may be most prestigious forms of building relationships with clients in opposition to routine and impersonal emailing.

Entrepreneurs in their approach to the client, show an excellent orientation to the present. Unfortunately, less then $50 \%$ of them anticipates future expectations of customers or tries to create the market, which it operates on (Fig. 2). So, in their future activities, SMEs should increase their activity in the area of client value management through extended analysis of the structure and potential of client capital.

Acknowledgement: This work was supported by the National Science Centre - research project no. DEC-2017/01/X/NS4/01606.

\section{References}

Aczel, A. D., \& Sounderpandian, J. (2008). Complete Business Statistics. Boston, MA: McGraw-Hill Irwin.

Adamska, M. (2012). Selected market conditions as determinants of entrepreneurship. In Proceedings of International Scientific Conference on MMK2012 Vol. III (pp. 906-914). Hradec Kralové: International Masaryk Conference.

Adamska, M., \& Minarova, M. (2014). Role of Learning Organization in Building Consumer Confidence. E\&M Economics and Management, 17(1), 62-72. https://dx.doi. org/10.15240/tul/001/2014-1-005

Belch, G. E., \& Belch, M. A. (2004). Advertising and promotion: An integrated marketing communications perspective. Boston, MA: McGraw-Hill.

Berezan, O., Krishen, A. S., Tanford, S., \& Raab, C. (2017). Style before substance? Building loyalty through marketing communication congruity. European Journal of Marketing, 51(7/8), 1332-1352. https://doi. org/10.1108/EJM-06-2015-0314

Berger, P. D., \& Nasr, N. I. (1998). Customer Lifetime Value: Marketing Models and Applications. Journal of Interactive Marketing, 12(1), 17-30. https://doi.org/10.1002/(SICI)15206653(199824)12:1<17::AID-DIR3>3.0.CO;2-K 
Bucalew, L. W., \& Pearson, W. H. (1982). Critical factors in the Chi-square test of independence: A technique for exploratory data analysis. Bulletin ofthe Psychonomic Society, 19(4), 225-226. https://doi.org/10.3758/ BF03330240

Cioppi, M., \& Buratti, A. (2009). The Strategic Role of Marketing Communication in the SME: the Case of Fornari SpA (Working Papers No. 0907). Urbino: University of Urbino Carlo Bo. Retrieved from https://www.researchgate.net/ publication/46476975_The_Strategic_Role_ of_Marketing_Communication_in_he_SME_ the_Case_of_Fornari_SpA

Coelho, P. S., \& Henseler, J. (2012). Creating customer loyalty through service customization. European Journal of Marketing, 46(3/4), 331-356. https://dx.doi. org/10.1108/03090561211202503

Donkers, B., Verhoef, P. C., \& de Jong, M. G. (2007). Modeling CLV: A test of competing models in the insurance industry. Quantitative Marketing and Economics, 5(2), 163-190. https://dx.doi.org/10.1007/s11129-006-9016-y

Eurostat Statistics Explained. (2018). Digital economy and society statistics enterprise. Retrieved from https://ec.europa.eu/ eurostat/statistics-explained/index.php/Digital_ economy_and_society_statistics_-_enterprises

Główny Urząd Statystyczny. (2017). Społeczeństwo informacyjne w Polsce w 2017 r. Opracowanie sygnalne. Retrieved from https://stat.gov.pl/files/gfx/portalinformacyjny/pl/ defaultaktualnosci/5497/2/7/1/spoleczenstwo_ informacyjne_w_polsce_w_2017.pdf

Gupta, S. J., Hanssens, D. M., Hardie, B., Kahn, W., Kumar, V., Lin, N., \& Sriram, N. (2006). Modeling Customer Lifetime Value. Journal of Service Research, 9(2), 139-155. https://dx.doi.org/10.1177/1094670506293810

Hsieh, H.-F., \& Shannon, S. E. (2005). Three Approaches to Qualitative Content Analysis. Qualitative Health Research, 15(9), 1277-1288. https://dx.doi.org/10.1177/1049732305276687

Internet World Stats. (2017). Internet Usage Statistics - Internet Users in the world by region. Retrieved December 31, 2017, from https://www.internetworldstats.com/stats.htm

Kotler, P., \& Armstrong, G. (2011). Principles of Marketing. Upper Saddle River, NJ: Pearson Prentice Hall.

Keller, K. L. (2009). Building strong brands in a modern marketing communications environment. Journal of Marketing
Communications, 15(2-3), 139-155. https://dx.doi.org/10.1080/13527260902757530

Kearney, M. W. (2017). Cramér's V. In M. R. Allen (Ed.), The SAGE Encyclopedia of Communication Research Methods. Los Angeles, CA: SAGE. http://dx.doi. org/10.4135/9781483381411.n107

Kitchen, P. J., \& Burgmann, I. (2010). Integrated Marketing Communication. In J. N. Sheth \& N. K. Malhotra (Eds.), Wiley International Encyclopedia of Marketing (Part 4: Advertising and Integrated Communication). Hoboken, NJ: John Wiley \& Sons. https://dx.doi. org/10.1002/9781444316568.wiem04001

Krum, C. (2012). Mobile Marketing. Erreichen Sie Ihre Zielgruppen (Fast) Überall. Boston, MA: Addison-Wesley, An imprint of Pearson. Retrieved from https://www.pearson. ch/download/media/9783827331106_SP.pdf

Lu, Y. (2014). How to Build Customer Loyalty to Grow Your Business (Infographic). Retrieved from https://www.inc.com/yolanda-lu/ customer-loyalty-for-small-business.html

Luxton, S., Reid, M., \& Mavondo, F. (2015). Integrated Marketing Communication Capability and Brand Performance. Journal of Advertising, 44(1), 37-46. https://dx.doi.org/10.1080/00913 367.2014.934938

Malär, L., Krohmer, H., Hoyer, W. D., \& Nyffenegger, B. (2011). Emotional Brand Attachment and Brand Personality: The Relative Importance of the Actual and the Ideal Self. Journal of Marketing, 75(4), 35-52. https://dx.doi.org/10.1509/jmkg.75.4.35

Maycotte, H. O. (2015). Customer Lifetime Value - The Only Metric That Matters. Forbes/Enterpreneurs. Retrieved from www. forbes.com/sites/homaycotte/2015/08/25/ customer-lifetime-value-the-only-metric-thatmatters/\#396fd31c3876

McHugh, M. L. (2013). The Chi-square test of independence. Biochemia medica, 23(2), 143149. http://dx.doi.org/10.11613/BM.2013.018

Mittal, V., \& Kamakura, W. A. (2001). Satisfaction, Repurchase Intent, and Repurchase Behavior: Investigating the Moderating Effect of Customer Characteristics. Journal of Marketing Research, 38(1), 131142. Retrieved from https://www.jstor.org/ stable/1558577

Mohammad, A. A. S., \& Alhamadani, S. Y. M. (2011). Service Quality Perspectives and Customer Satisfaction in Commercial Banks Working in Jordan. Middle Eastern Finance 
and Economics, 14, 60-72. Retrieved from https://www.uop.edu.jo/download/Research/ members/245_1760_Shir.pdf

Narodowe Centrum Nauki. (2017). Dokumentacja konkursowa Miniatura 1. Retrieved from https://www.ncn.gov.pl/ ogloszenia/konkursy/miniatura1

Neumann, M. M. (2007). Konsumentenvertrauen. Messung, Determinanten und Konsequenzen. Wiesbaden: Deutscher Universitats - Verlag, GWV Fachverlag $\mathrm{GmbH}$. Retrieved from http://books.google.pl

Ramasobana, M. (2017). Marketing Communication and the Performance of Small and Medium Enterprises in Polokwane Local Municipality. In The 2nd Annual International Conference on Public Administration and Development Alternatives, Botswana (pp. 113-120). Retrieved from https://pdfs.semanticscholar.org/34d6/ 4545ff427dc28728718b30c9876dbf6c44c1.pdf

Saeed, R., Naeem, B., Bilal, M., \& Naz, U. (2013). Integrated Marketing Communication: A Review Paper. Interdisciplinary Journal Of Contemporary Research In Business, 5(5), 124-133. Retrieved from https://journalarchieves35.webs.com/124-133.pdf

Sargeant, A., \& Lee, S. (2004). Donor Trust and Relationship Commitment in the U.K. Charity Sector: The Impact on Behavior. Nonprofit and Voluntary Sector Quarterly, 33(2), 185-202. http://dx.doi.org/10.1177/0899764004263321

Smaoui, F., \& Temessek Behi, A. (2011). Brand engagement vs. brand attachment: which boundaries? Micro \& Macro Marketing, 20(2), 255-272. https://dx.doi.org/10.1431/35139

Thomson M., Mcinnis D. J., \& Park, C. W. (2005). The Ties that Bind: Measuring the
Strength of Consumers' Emotional Attachments to Brands. Journal of Consumer Psychology, 15(1), 77-91. https://dx.doi.org/10.1207/ s15327663jcp1501_10

Tirenni, G., Labbi, A., Berrospi, C., Elisseeff, A., Bhose, T., Pauro, K., \& Pöyhönen, S. (2007). Customer Equity and Lifetime Management (CELM) Finnair Case Study. Marketing Science, 26(4), 553-565. https://dx.doi.org/10.1287/ mksc. 1060.0249

Varadarajan, R. (2010). Strategic Marketing and Marketing Strategy: Domain, Definition, Fundamental Issues and Foundational Premises. Journal of the Academy Marketing Science, 38(2), 119-140. https://dx.doi. org/10.1007/s11747-009-0176-7

Venetis, K. A., \& Ghauri, P. N. (2004). Service quality and customer retention: building long-term relationships. European Journal of Marketing, 38(11/12), 1577-1598. https://dx.doi.org/10.1108/03090560410560254

Venkatesan, R., \& Kumar, V. (2004). A Customer Lifetime Value Framework for Customer Selection and Resource Allocation Strategy. Journal of Marketing, 68(4), 106-125. https://dx.doi.org/10.1509/jmkg.68.4.106.42728

Villanueva, J., \& Hanssens, D. M. (2007). Customer Equity: Measurement, Management and Research Opportunities. Foundations and Trends in Marketing, 1(1), 1-95. http://dx.doi. org/10.1561/1700000002

Wiktor, J. W. (2002). Modele komunikacji marketingowej. Zeszyty naukowe Akademii Ekonomicznej w Krakowie, 603, 115-124. Retrieved from http://yadda.icm.edu.pl/ yadda/element/bwmeta1.element.ekonelement-000000014748 